\title{
Sodium sulfite research and microbiological analysis of ground beef and fresh
}

\author{
sausage \\ Pesquisa de sulfito de sódio e análise microbiológica em carne moída e linguiça frescal \\ Investigación de sulfito de sodio y análisis microbiológico en carnes molida y embutidos frescos
}

Received: 03/17/2021 | Reviewed: 03/26/2021 | Accept: 03/29/2021 | Published: 04/06/2021

\author{
Ana Jessika Santos do Nascimento \\ ORCID: https://orcid.org/0000-0003-0677-4333 \\ Centro Universitário Maurício de Nassau, Brasil \\ E-mail: anajessikanutri@gmail.com \\ Neide Kazue Sakugawa Shinohara \\ ORCID: https://orcid.org/0000-0001-8356-874X \\ Universidade Federal Rural de Pernambuco, Brasil \\ E-mail: neideshinohara@gmail.com \\ Jairo Luiz de Araujo Pereira \\ ORCID: https://orcid.org/0000-0003-3222-8782 \\ Universidade Federal Rural de Pernambuco, Brasil \\ E-mail: jairo.luizdearaujo@gmail.com \\ Allan Matheus de Souza Silva \\ ORCID: https://orcid.org/0000-0003-1096-7445 \\ Universidade Federal Rural de Pernambuco, Brasil \\ E-mail: allanmatheus10@hotmail.com \\ Amanda Mirelly Santos Sobral \\ ORCID: https://orcid.org/0000-0002-6598-1140 \\ Universidade Federal Rural de Pernambuco, Brasil \\ E-mail: amandamssobral@gmail.com \\ Thiago Ramos da Silva \\ ORCID: https://orcid.org/0000-0002-0453-8794 \\ Universidade Federal Rural de Pernambuco, Brasil \\ E-mail: thiagorammos@gmail.com
}

\begin{abstract}
In general, the meat contains nutrients of high biological value and susceptible to contamination by enteropathogens. One way of minimizing/eliminating this contamination is the use of food additives, in the case of meat, usually sodium sulphite. This technological resource is used to inhibit the growth of pathogenic bacteria such as Salmonella spp. and thermotolerant coliforms, mandatory parameters foreseen in sanitary legislation. Therefore, the objective of this article was to evaluate the presence of sodium sulfite and detection of Salmonella spp., total and thermotolerant coliforms in 23 samples of ground beef and 7 of fresh pork sausage, marketed in open markets and public markets of Grande Recife - PE. In a total of 30 samples analyzed, it was not detected in any presence of sodium sulphite. In the microbiological assays, also it was not detected the presence of Salmonella spp. and thermotolerant coliforms. The Total Coliforms was found in 20 meat samples (87\%), at the maximum concentration of $35 \mathrm{MPN} / \mathrm{g}^{-1}$ and in all sausages (100\%) at the concentration of 35 to $36 \mathrm{MPN} / \mathrm{g}^{-1}$. Although the Total Coliforms is not considered pathogenic, the presence of this indicates unsatisfactory sanitary conditions in the production, which may constitute biological risk for vulnerable groups.
\end{abstract}

Keywords: Food additives; Beef; Coliforms; Conservation; Sausage.

\section{Resumo}

A carne em geral apresenta nutrientes de alto valor biológico e assim passível de contaminação por patógenos. Uma forma de minimizar/eliminar essa contaminação é o uso de aditivos alimentares, que no caso da carne, a alternativa é o sulfito de sódio. Essa prática tecnológica é inibe o crescimento de bactérias patogênicas como a Salmonella spp. e coliformes termotolerantes, parâmetros obrigatórios previstos em legislação sanitária para as carnes. Portanto o objetivo desse trabalho foi o de avaliar a presença de sulfito de sódio e detecção de Salmonella spp., coliformes totais e termotolerantes em 23 amostras de carne bovina moída e 7 amostras de linguiça fresh suína, comercializadas em feiras livres e mercados públicos do Grande Recife - PE. Do total de 30 amostras analisadas, não foi detectado a presença de sulfito de sódio. Quanto à detecção para Salmonella spp. e coliformes termotolerantes, estes se mostraram ausentes nesse estudo. O coliforme total foi encontrado em 20 amostras de carne (87\%) na concentração de 3 a 35 $\mathrm{NMP} / \mathrm{g}^{-1}$ e em $100 \%$ das amostras de linguiça (n7) na concentração de 35 a $36 \mathrm{NMP} / \mathrm{g}^{-1}$. Apesar do coliforme total 
não ser considerado patogênico a presença deste indica condições sanitárias insatisfatórias no ambiente de produção, podendo se constituir risco biológico principalmente para grupos vulneráveis.

Palavras-chave: Aditivo alimentar; Carne bovina; Coliformes; Conservação; Embutido.

\section{Resumen}

La carne en general tiene nutrientes de alto valor biológico y, por lo tanto, susceptibles a la contaminación por patógenos. Una forma de minimizar / eliminar esta contaminación es el uso de aditivos alimentarios, que en el caso de la carne, la alternativa es el sulfito de sodio. Esta práctica tecnológica es inhibir el crecimiento de bacterias patógenas como Salmonella spp. y coliformes termotolerantes, parámetros obligatorios previstos en la legislación sanitaria para la carne. Por lo tanto, el objetivo de este trabajo fue evaluar la presencia de sulfito de sodio y la detección de Salmonella spp., Coliformes totales y termotolerantes en 23 muestras de carne molida y 7 muestras de salchicha de cerdo fresca, que se venden en mercados abiertos y mercados públicos en el Grande Recife - PE. Del total de 30 muestras analizadas, no se detectó la presencia de sulfito de sodio. Con respecto a la detección de Salmonella spp. y coliformes termotolerantes, estos estuvieron ausentes en este estudio. El coliforme total se encontró en 20 muestras de carne (87\%) a una concentración de 3 a 35 NMP / g-1 y en el 100\% de las muestras de salchichas (n7) a una concentración de 35 a $36 \mathrm{NMP} / \mathrm{g}-1$. Aunque el coliforme total no se considera patógeno, su presencia indica condiciones sanitarias insatisfactorias en el entorno de producción, lo que puede ser un riesgo biológico, especialmente para los grupos vulnerables.

Palabras clave: Aditivo alimentario; Carne de vacuno; Coliformes; Conservación; Incrustado.

\section{Introduction}

In Brazil, beef is used as an important source of food and has increased consumption in recent decades. Because it is a source of proteins of high biological value, it has important vitamins, lipids, minerals and amino acids needed by the body. Among the products obtained from beef, ground meat stands out for its high consumption, since it is affordable, besides being used in several ways in meals (Almeida et al., 2015; Damer et al., 2016; Monteiro et al., 2018).

However, ground meat has a higher microbial load than whole pieces, because it is handled more and has an increased contact surface. It is a product obtained from other cuts of handled meat and a single contaminated portion can spread its microbiota to all the rest. Besides the fact that grinders and cutting tools are also important sources of contamination, as they are generally not properly sanitized in a proper manner and frequency (Ferreira \& Simm, 2012).

After undergoing the milling process and being exposed to the environment, meat may acquire unsatisfactory sensory characteristics, suffer rapid deterioration due to its large amount of nutrients, high water activity and pH close to neutrality, being pointed out as a substrate for the development of pathogenic or deteriorating microorganisms (Germano \& Germano, 2015; Jay, 2005; Shinohara et al., 2017).

As a result of these extrinsic and intrinsic factors of meat, commercial practice intentionally uses some malicious additives to avoid losses and mask inferior quality, thus conferring greater risk to consumer health (Melo\& Resende,2012). A fraudulent action to mask the losses occurred during the processing and storage of meat, is the addition of sodium sulfite, a technological resource that has antimicrobial properties (Costa, 2018).

Another important segment of the meat products industry, which has shown significant expansion and high competitiveness are the sausages, since the consumption of products such as hamburgers, meatballs, and mortadellas, that have become part of the food habit of a large part of modern society. The accessible price, the practicality in the preparation and the contribution in nutrients of these sausages, contribute to the supply of proteins, mainly for the population with lower purchasing power (Melo Filho et al., 2004; Oliveira et al., 2013), having in the artisan production of sausages, an alternative of protein source allied to the practicality of consumption.

Fresh sausages are products of animal origin, have high water activity and if handled incorrectly and not subjected to proper heat treatment, may favor contamination by pathogenic and/or deteriorating microorganisms. Thus, the lack of good handling practices, together with the food, facilitates cross contamination, leading to changes in the colour, aroma and taste of the product, putting at biological risk the commensal (Camara et al., 2015; Leal et al., 2019). 
The commercialization of handmade sausages of clandestine brands, without health guidance and inspection, exposes consumers due to the ingestion of meat product contaminated by pathogens, associated with the use of unauthorized additives or above the maximum limit allowed with conservation effect, supported by legislation, increase the risk of appearance of biological outbreaks and chemical intoxication, and may evolve to more severe pathologies or death (Paula et al., 2009; Shinohara et al. 2017).

Among food additives, sodium sulphite is often used in meat products to preserve colour and eliminate strong odours, giving a fresh product appearance, thus masking possible deterioration of the meat (Melo et al., 2012). However, the consumption of meat and meat products containing sulfite, without observance of the legal concentration allowed, may evolve into pathologies such as urticaria, allergies and asthmatic crises, putting at risk the physical integrity of consumers, generating impact on public health (Bonfada et al., 2012).

The sanitary quality of products of animal origin is the constant concern and supervision of the federal regulatory agencies, responsible for monitoring and follow-up of production until the commercialization of food, because meat products can suffer cross contamination, and thus transmit pathogenic microorganisms that contribute to the increase of Food-Borne Diseases (DTA). The contamination of this product occurs mainly by Salmonella spp., total coliforms and thermotolerants (Germano \& Germano, 2015; Sales et al., 2016; Silva et al.2016; De Souza et al., 2019).

To guarantee safe food, the detection of enteric pathogens and the presence of sodium sulfite in ground beef and fresh sausages are important quality parameters to evaluate the hygienic-sanitary and chemical conditions of meat sold in the Greater Recife Region of Pernambuco, since the presence of these biological organisms and chemical compounds indicate failures of good handling practices throughout processing.

\section{Methodology}

A qualitative, quantitative and transversal research was carried out through sales of ground meat and fresh sausages, collected in 20 applications that sell meat products from Grande Recife in Pernambuco. A survey carried out in March and August 2019, 30 samples were collected, being 23 samples of ground meat (300 grams) and 7 samples of fresh sausage (200 grams). Immediately after collection, the samples were identified and conditioned in isothermal boxes with returnable ice packs and transported to the Food Analysis Laboratory of the Universidade Federal Rural de Pernambuco. Analyzes were performed to verify the presence of sodium sulfite, count and detection of Total Coliforms, Escherichia coli and presence/absence of Salmonella spp.

The detection of sodium sulfite was carried out through the test for sulfite with malachite green (IAL, 2008). The 3.5 grams of ground meat was transferred in a porcelain dish and $0.5 \mathrm{ml}$ of $0.02 \%$ malachite green solution was added. The sample and the solution were mixed for about 2 minutes. If there is sodium sulfite in the sample, the malachite green solution will discolor, and in the absence, the sample will turn bluish green. The physical-chemical analysis was done in triplicate.

For Total Coliforms count, Escherichia coli and Salmonella spp. rapid tests were used, CompactDry® kits, respectively CompactDry TC®, CompactDry EC®, CompactDry SL®, methodology approved by APHA, AOAC, FDA, I.C.M.S.F. and Silva et al. (2017) for microbiological food tests. Microbiological analyzes were performed in triplicate.

\section{Results and Discussion}

The use of food additives for conservation purposes is prohibited whenever there is evidence or suspicion that it is not safe for human consumption; interfere sensitively and unfavorably in the nutritional value of the food; be used to cover up flaws in the processing and/or in the techniques of manipulation, alteration or adulteration of the raw material or the product already 
prepared or to induce the consumer to error, mistake or confusion (Brasil, 1997).

Normative Instruction (IN) No. 83 (Brasila, 2003) of the Ministry of Agriculture and Livestock, which approves the technical regulations on identity and quality of ground beef prohibits the addition of preservative substances in it. Like Normative Instruction (IN) No. 51 (Brasilb, 2006), which adopts the technical regulation for the attribution of additives and their limits in the category of meat and meat products, it does not authorize the application of preservatives in fresh, chilled and frozen meat and does not mention sodium sulfite among the preservatives allowed in any category of meat products.

In this article, all samples (n30), both ground meat and fresh sausages, showed a negative result in the investigation for the presence of sodium sulfite (Tables 1 and 2). These results corroborate with Fernandes et al. (2014), who also researched sodium sulfite in samples of ground meat sold in the city of Recife in Pernambuco. The results of the two surveys, carried out at different times in the same city, indicate that this type of fraud is not a routine practice.

Table 1. Average results for the detection of sodium sulfite and microbiological analyzes in ground meat from the Grande Recife - PE.

\begin{tabular}{ccccc}
\hline Sample & $\begin{array}{c}\text { Sodium Sulphite } \\
(\mathrm{P} / \mathrm{A})\end{array}$ & $\begin{array}{c}\text { Salmonella spp. } \\
\left(\text { CFU } / \mathrm{g}^{-1}\right)\end{array}$ & $\begin{array}{c}\text { Escherichia coli } \\
\left(\mathrm{CFU} / \mathrm{g}^{-1}\right)\end{array}$ & $\begin{array}{c}\text { Total Coliforms } \\
\left(\mathrm{MPN} / \mathrm{g}^{-1}\right)\end{array}$ \\
\hline 1 & Absence & Absence & $<10$ & 3,0 \\
2 & Absence & Absence & $<10$ & 3,0 \\
3 & Absence & Absence & $<10$ & 27 \\
4 & Absence & Absence & $<10$ & 35 \\
5 & Absence & Absence & $<10$ & 35 \\
6 & Absence & Absence & $<10$ & 35 \\
7 & Absence & Absence & $<10$ & 35 \\
8 & Absence & Absence & $<10$ & 27 \\
9 & Absence & Absence & $<10$ & 6,2 \\
10 & Absence & Absence & $<10$ & 35 \\
11 & Absence & Absence & $<10$ & 6,2 \\
12 & Absence & Absence & $<10$ & 7,2 \\
13 & Absence & Absence & $<10$ & 3,2 \\
14 & Absence & Absence & $<10$ & 27 \\
15 & Absence & Absence & $<10$ & 35 \\
16 & Absence & Absence & $<10$ & 6,1 \\
17 & Absence & Absence & $<10$ & 35 \\
18 & Absence & Absence & $<10$ & 11 \\
19 & Absence & Absence & $<10$ & 35 \\
20 & Absence & Absence & $<10$ & $<3,0$ \\
21 & Absence & Absence & $<10$ & $<3,0$ \\
22 & Absence & Absence & $<10$ & $<3,0$ \\
23 & Absence & Absence & $<10$ & $-6-0.0-10$
\end{tabular}

P/A - Presence/Absence; CFU/g-1 - Colony-Forming Unit/gram; MPN/g-1 - Most Probable Number/gram. Source: Authors. 
Table 2. Average results for the detection of sodium sulfite and microbiological analyzes in fresh sausages from the Grande Recife - PE.

\begin{tabular}{ccccc}
\hline Sample & $\begin{array}{c}\text { Sodium Sulphite } \\
(\mathrm{P} / \mathrm{A})\end{array}$ & $\begin{array}{c}\text { Salmonella } \mathrm{spp} . \\
(\mathrm{CFU} / \mathrm{g}-1)\end{array}$ & $\begin{array}{c}\text { Escherichia coli } \\
(\mathrm{CFU} / \mathrm{g}-1)\end{array}$ & $\begin{array}{c}\text { Total Coliforms } \\
(\mathrm{MPN} / \mathrm{g}-1)\end{array}$ \\
\hline 01 & Absence & Absence & $<10$ & 35 \\
02 & Absence & Absence & $<10$ & 35 \\
03 & Absence & Absence & $<10$ & 35 \\
04 & Absence & Absence & $<10$ & 36 \\
05 & Absence & Absence & $<10$ & 35 \\
06 & Absence & Absence & $<10$ & 35 \\
07 & Absence & Absence & $<10$ & 35 \\
\hline
\end{tabular}

P/A - Presence/Absence; CFU/g-1 - Colony-Forming Unit/gram; MPN/g-1 - Most Probable Number/gram. Source: Authors.

In the study by Oliveira et al. (2017), the presence of sodium sulfite was not found in ground beef sold in butchers in Bom Jesus do Piauí. In another study by Costa (2018), all samples of ground meat also showed negative results for the fraud test of addition of sodium sulfite, in the city of Campo Mourão in Paraná. In both surveys, the samples are in accordance with current federal legislation, where it prohibits adding this additive to fresh meat.

Although the sodium sulfite fraud in meat in the municipality of Recife (PE) has not been verified, studies carried out in other states indicate the occurrence of this fraud. Analyzes carried out by Bonfada et al. (2012), when researching the presence of sodium sulfite in ground meat sold in the municipality of Porto Alegre - RS, revealed the presence of sodium sulfite in $3.63 \%$ of the samples. In Rio de Janeiro, when checking the presence of preservative additives in ground beef, Silva et al. (2009), also found the addition of sodium sulfite in $11.42 \%$ of the meat samples, characterizing the non-compliance with the current legislation, putting the consumer's health at risk with the intention of profit.

Regarding Salmonella spp., no samples of ground meat and fresh sausages in this study (TABLES 1 and 2) identified the existence of this enteropathogen. A similar result was found by Almeida et al. (2018), Costa (2018), Lundgren et al. (2009) and Oliveira et al. (2017), who also did not find Salmonella spp. in ground beef.

However, a research by Cruz et al. (2018), verified the existence of Salmonella spp. in 6.5\% of ground beef samples analyzed in the Southern Fluminense Region. In another study, Alberti and Nava. (2014), found the apparition of this same microorganism in $67 \%$ of fresh sausage samples sold in bulk in supermarkets in Xaxim - SC.

In Brazil, Salmonella spp. are considered to be the most important cause of foodborne illnesses (Chagas et al., 2017; Moura et al., 2007), so food, especially meat, due to its perishability, needs constant monitoring by the inspection agencies so that the health of the populations does not occur.

Regarding the apparition of Escherichia coli (TABLES 1 and 2), none of the analyzed samples of ground meat and fresh sausage showed growth for this pathogen, thus being within the current legal standard that establishes a maximum limit of $103 \mathrm{MPN} / \mathrm{g}$, that is, they are suitable for consumption in view of this biological parameter (BRASILc, 2019; BRASILd, 2019; SILVA et al., 2017).

In the study by Monteiro et al. (2018), the presence of thermotolerant coliforms was found in $87 \%$ of the beef minced meat investigated, but remaining within the limits allowed by the legislation for commercialization. Oliveira et al. (2017), Escherichia coli was detected in $46.66 \%$ of ground meat samples. The authors point out that the detection of $E$. coli, arouses the need for better slaughter, transport and handling conditions meat, to prevent food contact with gastrointestinal material and thus promote cross contamination and cause a food outbreak.

The detection of Total Coliforms was found in about $87 \%(24 / 27)$ of ground meat samples, at a concentration of 3.0 to $35 \mathrm{MPNg}^{-1}$. In the samples of fresh sausages, $100 \%$ of the samples showed growth in the concentration of 35 to $36 \mathrm{MPNg}^{-1}$. 
These findings would not prohibit the consumption of minced meat and fresh sausages analyzed in the light of health standards (Brasilc, 2019; Brasild, 2019). The Total Coliforms count was performed in this research to evaluate the hygienic sanitary conditions to which the products were submitted.

However, according to Almeida et al. (2018) it is necessary to be cautious when detecting the presence of Total Coliforms in food, as it is indicative of the incorrect hygiene of the manipulator, equipment and/or environment. In the study by Damer et al. (2016), researching Total Coliforms in ground meat, found 100\% (n14) of samples contaminated with total and thermotolerant coliform.

In view of the concern regarding food safety and safe consumption, investments in public policies aimed at health education and the effective performance of surveillance systems as useful alternatives in the dissemination, awareness, prevention and control of diseases that offer serious risks and damage to health are necessary (Melo et al., 2012).

\section{Conclusion}

The results showed absence of sodium sulfite, Salmonella spp. and Escherichia coli, so all samples met the current legislation for meat and meat products. However, the count found of Total Coliforms indicates that there were failures in sanitary hygienic control along the production chain, storage and distribution of ground beef and fresh sausage.

\section{References}

Alberti, J., \& Nava, A. (2014). Avaliação Higiênico-Sanitária De Linguiças Tipo Frescal Comercializadas A Granel Por Supermercados E Produzidas Artesanalmente No Município de Xaxim, SC. Unoesc \& Ciência, Joaçaba, 5(1), 41-48.

Almeida, B. S., Monteiro, W. A., \& Bezerra, F. Y. (2015). Perfil Microbiológico da carne moída comercializada no Município de Juazeiro do Norte, Ceará. Revista Interfaces: Saúde, humanas e tecnologia, 2(7),2-8.

Almeida, C. R., Massago, M., \& Boni, S. M. (2018). Avaliação Higiênico-Sanitária De Carne Moída Comercializada Em Açougues Da Cidade De Sarandi, Pr, Brasil. Infarma-Ciências Farmacêuticas, 30(2), 110-114.

AOAC. (2005). Association of Official Analytical Chemists. Official methods of analysis. (18th ed.).

APHA. - American Public Health Association. (2005). Standard Methods for the Examination of Water and Wastewater (21st ed.) American Public Health Association, Washington DC, USA.

Brasil. - Agência Nacional de Vigilância Sanitária. Portaria n 540 SVS/MS (1997). Aprova o Regulamento Técnico: Aditivos Alimentares. Diário Oficial da União. Brasília, DF, Brasil. <http://bvsms.saude.gov.br/bvs/saudelegis/svs1/1997/prt0540_27_10_1997.html>

Brasila - Ministério da Agricultura, Pecuária e Abastecimento. Instrução Normativa no 83 (2003). Aprova os regulamentos técnicos de identidade e qualidade de carne bovina em conserva e carne moída de bovino. Diário Oficial da União. Brasília, DF, Brasil. <https://pesquisa.in.gov.br/imprensa/jsp/visualiza/index.jsp?data=24/11/2003\&jornal=1 \&pagina=29\&totalArquivos=108>

Brasilb - Ministério da Agricultura, Pecuária e Abastecimento. Instrução Normativa no 51 (2006). Adota o regulamento técnico de atribuição de aditivos, e seus limites em categorias específicas de alimentos. Diário Oficial da União. Brasília, DF, Brasil. <https://www.jusbrasil.com.br/diarios/412082/pg-14-secao-1diario-oficial-da-uniao-dou-de-04-01-2007>

Brasilc - Agência Nacional de Vigilância Sanitária. Resolução da Diretoria - RDC no 331 (2019). Estabelece os padrões microbiológicos de alimentos e sua aplicação. Diário Oficial da União. Brasília, DF, Brasil. 〈https://www.in.gov.br/en/web/dou/-/resolucao-rdc-n-331-de-23-de-dezembro-de-2019-235332272>

Brasild - Ministério da Saúde. Instrução Normativa $n^{\circ} 60$ (2019). Estabelece as listas de padrões microbiológicos para alimentos. Diário Oficial da Uniãa. Brasília, DF, Brasil. <https://www.in.gov.br/en/web/dou/-/instrucao-normativa-n-60-de-23-de-dezembro-de-2019-235332356>

Bonfada, D. H., Kindlein, L., Vilarinho, R. C. \& Bergmann, G. P. (2012). Presença de sulfito de sódio e sua influência nas características físico-químicas e microbiológicas de carnes bovinas resfriadas. Acta Scientiae Veterinariae, 40(2), 1036.

Camara, S. A. V., \& Nascimento, C. B. (2015). Avaliação microbiológica de linguiça frescal. Revista Estação Científica - Centro Universitário Estácio de Juiz de Fora. Edição Especial VII Seminário de Pesquisa da Estácio e III Jornada de Científica da UNESA 6, 1-10.

Chagas, V. P. S., Santos, C. R., Reis, W. C. S, Santos, A. B. P., Bezerra, M. P. F. \& Seixas, V. N. C. (2017). Investigação de Salmonella spp. em produtos cárneos de matadouros frigoríficos do estado do Pará no período de 2014-2015. Revista Brasileira de Higiene e Sanidade Animal, 11(1), 1-7.

Costa, L. C. (2018). Avaliação higiênico-sanitária e físico-química de carne in natura comercializada em campo mourão - PR. Revista Uningá Review, 33, 5565. 
Cruz, F. M., Souza, L. F. O., Teixeira, A. S., Santos, A. C. P., Santos, K. G., Silva, G. B. R., Moreira, S. C. \& Santos, V. H. S. B. (2018). Avaliação microbiológica de amostras de carne moída coletadas de diferentes pontos comerciais da Região Sul Fluminense. Simpósio, 6.

Damer, J. S., Dill, R., Gusmão, A. \& Moresco, T. (2016). Contaminação de carne bovina moída por Escherichia coli e Salmonella sp. Revista Contexto \& Saúde, 14(26), 20-27.

De Souza, L. M., Amaral, C. A. A., \& Liboredo, J. C. (2019). Conhecimento de manipuladores de alimentos sobre higiene e condições sanitárias na produção de comida japonesa. Brazilian Journal of Development, 5(12), 30684-30696.

FDA - Food and Drug Administration. (2001). Bacteriological Analytical Manual, (8th ed.), Rev. A, AOAC International, Gaithersburg, MD.

Fernandes, M. F. T. S., Cavalcanti, E. F. T. S. F., da Silva, J. G., de Albuquerque, P. P. F., \& de Moura, A. P. B. L. (2014). Pesquisa de sulfito de sódio em amostras de carne moída comercializadas na cidade do Recife, Pernambuco, Brasil. Brazilian Journal of Veterinary Medicine, $36(1)$, $42-44$.

Ferreira, R. S., \& Simm, E. M. (2012). Análise microbiológica da carne moída de um açougue da região central do município de Pará de Minas/MG. SYNTHESIS| Revistal Digital FAPAM, 3(1), 37-61.

Germano, P. M. L., \& Germano, M. I. S. (2015). Higiene e vigilância sanitária de alimentos. In Higiene e vigilância sanitária de alimentos (pp. 1077-1077).

IAL. (2008). Instituto Adolfo Lutz. Métodos físico-químicos para análise de alimentos. Instituto Adolfo Lutz, 4, 1020.

ICMSF. (2002). International Commission On Microbiological Specifications for Foods. Microrganisms in Food 7. Micobiological Testing in Food Safety Management. Kluwer Academic/ Plenum Publishers

Jay, J. M. (2005). Microbiologia de Alimentos. Artmed, 6.

Leal, M. A. B. F., Lima, C. E. B. D., Mascarenhas, M. D. M., Rodrigues, M. T. P., Paiva, S. S. C. D., Sousa, C. R. D. O., \& Veloso, V. R. (2019). Associação entre fatores sociodemográficos e comportamentos de risco à saúde cardiovascular de adolescentes brasileiros com 13 a 17 anos: dados da Pesquisa Nacional de Saúde do Escolar 2015. Epidemiologia e Serviços de Saúde, 28, e2018315.

Lundgren, P. U., SILVA, J. A., Maciel, J. F., \& Fernandes, T. M. (2009). Perfil da qualidade higiênico-sanitária da carne bovina comercializada em feiras livres e mercados públicos de João Pessoa/PB-Brasil. Alimentos e Nutrição Araraquara, 20(1), 113-119.

Melo, C. F., \& Resende, A. (2012). Quantificação De Coliformes Termotolerantes Em Carne Bovina Moída Comercializadas Em Açougues Do Distrito Federal. Ensaios e Ciência C Biológicas Agrárias e da Saúde, 16(3),2-8.

Melo Filho, A. B. D., Biscontini, T. M. B., \& Andrade, S. A. C. (2004). Níveis de nitrito e nitrato em salsichas comercializadas na região metropolitana do Recife. Food Science and Technology, 24(3), 390-392.

Monteiro, C., Cannon, G., Moubarac, J., Levy, R., Louzada, M., \& Jaime, P. (2018). The UN Decade of Nutrition, the NOVA food classification and the trouble with ultra-processing. Public Health Nutrition, 21(1), 5-17.

Moura, A. P. B. L., Pinheiro Júnior, J. W., Oliveira, R. B. A., Duarte, D. A. M., Ribeiro, A. R., \& Reis, E. M. F. (2007). Pesquisa de coliformes termotolerantes, totais e Salmonella spp. em carnes caprinas comercializadas na cidade do Recife, Pernambuco. Arq Inst Biol (Sao Paulo), 74, $293-299$.

Oliveira, D. F. D., Coelho, A. R., Burgardt, V. D. C. D. F., Hashimoto, E. H., Lunkes, A. M., Marchi, J. F., \& Tonial, I. B. (2013). Alternativas para um produto cárneo mais saudável: uma revisão. Brazilian Journal of Food Technology, 16(3), 163-174.

Oliveira, M. S., Castro, S. V., Pinto, O. C., Nunes, G. S., Natylane, E. F., Machado, F. C. F., \& Júnior, A. A. N. M. (2017). Qualidade físico-química e microbiológica da carne moída de bovino em açougues. REDVET. Revista Electrónica de Veterinaria, 18(12), 1-13.

Paula, D. C., Frutuozo, J. R., Santos, T. D., \& Pinheiro, A. L. B. (2009). Investigação do Teor de Nitrito em Linguiças do Tipo Toscana, Comercializadas na Região de Franca-SP. Revista Brasileira Multidisciplinar, 12(2), 101-118.

Sales, W. B., Kuchak, K. C., \& Caveião, C. (2016). Determinação de coliformes totais e termotolerantes em hambúrgueres vendidos em fast foods na cidade de Curitiba-Paraná. Revista da Universidade Vale do Rio Verde, 14(2), 412-420.

Santos, V. H. S. B., Teixeira, S. M., Santos, A. C. P., Silva, G. B. R., Moreira, S. C., Santos, K. G., Soares, L. C. \& Cruz, F. M. (2017). Avaliação Microbiológica de Carne Moída Coletada de Diferentes Pontos Comerciais da Região Sul Fluminense. In: $17^{\circ}$ CONIC-SEMESP, São Paulo. Anais do Conic-Semesp, 5.

Shinohara, N. K. S., Nascimento, K. S. M., Lima, G. S., Padilha, M. R. F., Almeida, M. L. \& Machado, J. (2017). Manipulation in Industrialized Meat Products| Manipulação em produtos de carne industrializados. Revista Geama, 47-52.

Silva C., Monteiro M. L. G., Ribeiro R. O. R., Guimaraes C. F. M., Mano S. B., Pardi H. S. \& Mársico E. T. (2009). Presença de aditivos conservantes (nitrito e sulfito) em carnes bovinas moídas, comercializadas em mercados varejistas. Revista Brasileira de Ciência Veterinária, 16(1), 33-36.

Silva, N., Junqueira, V. C. A., Silveira, N. F. A., Taniwaki, M. H., Gomes, R. A. R., Okazaki, M; M. (2017). Manual de métodos de análise microbiológica de alimentos (5th ed.). Livraria Varela. 